Ivan Peko ${ }^{1}$, Petar Ljumović ${ }^{*}$, Bogdan Nedić ${ }^{2}$, Marko Dunđer ${ }^{3}$

${ }^{1}$ University of Split, Faculty of Electrical Engineering, Mechanical Engineering and Naval Architecture, Split, Croatia

${ }^{2}$ University of Kragujevac, Faculty of Engineering, Kragujevac,

Serbia, ${ }^{3}$ University of Rijeka, Study of Polytechnic, Rijeka, Croatia
Scientific paper

ISSN 0351-9465, E-ISSN 2466-2585

UDC: $621.96: 669.15: 620.18$

doi: $10.5937 /$ zasmat1902174P

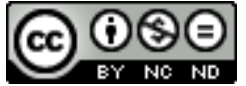

Zastita Materijala 60 (2)

$174-181(2019)$

\title{
Analysis of the heat affected zone in plasma jet cutting process of the aluminium alloy EN AW 5083
}

\begin{abstract}
Plasma jet cutting process is a well-known nonconventional thermo-electrical manufacturing process that is widely used in metal and shipbuilding industry. It uses the energy of highly ionized gas to cut various types of metal materials. Cutting process is determined by technological parameters whose values define the final cut quality results. Cut quality can be defined considering different characteristics such as: kerf width, bevel angle, surface roughness, dross height and heat affected zone. In this paper, a research on the influence of variable process parameters on the heat affected zone (HAZ) was conducted. An investigated material was aluminium alloy EN AW 5083. HAZ analysis was done by measuring hardness changes on the specimen cross sections and by microscopic observation of the material structure.
\end{abstract}

Keywords: plasma jet cutting, heat affected zone, aluminium, EN AW 5083, hardness, material structure.

\section{INTRODUCTION}

Plasma jet cutting process alongside laser cutting process is the most common nonconventional thermo-electrical manufacturing procedure today. In this process, the injection of the gas into electrical arc creates a high intensity plasma jet that has sufficient amount of energy to melt the workpiece and to blow the molten metal away from the cut. This process can be used to cut various types of materials such as mild steels, stainless steels, aluminium alloys, copper alloys, titanium alloys etc., at various thicknesses [1]. The main advantages that position this technology in front of laser cutting process are lower investments, long consumables life, lower production costs per part and high productivity [2]. Beside the production costs, the main objective of this cutting process is to obtain the best possible final cut quality. According to that, many authors have investigated the influence of the process parameters on the cut quality characteristics aiming to find an optimal cutting area [3-10].

\footnotetext{
${ }^{*}$ Corresponding author: Petar Ljumović

E-mail: petarlj@fesb.hr

Paper received: 02. 01. 2019.

Paper accepted: 15. 02. 2019.

Paper is available on the website:

www.idk.org.rs/journal
}

One of the most important cut quality characteristics is the heat affected zone. It can be defined as a part of material where the structure changes can be expected because of the heat input during the plasma jet cutting process. In this paper, an investigation of the influence of process parameters such as cutting speed and arc current on the heat affected zone was conducted. The heat affected zone was analysed by hardness measurements on the specimen cross sections. Metallographic analysis of the material structure was done as well. The material used for experimental work was aluminium alloy EN AW 5083.

\section{EXPERIMENTAL WORK}

In this paper, the heat affected zone was analyzed. The analysis was conducted on samples (cuts) of $3 \mathrm{~mm}$ thick sheet, cut with different process factor values (Table1).

For heat affected zone determination purposes, micro-hardness testing of the samples crosssection was done, as well as the microstructure analysis. The complete analysis was conducted at the Faculty of Electrical Engineering, Mechanical Engineering and Naval Architecture, University of Split. 
Table 1. Samples for heat affected zone analysis

Tablica 1. Uzorci za analizu zone utjecaja topline

\begin{tabular}{|c|c|c|c|}
\hline $\begin{array}{c}\text { No. of } \\
\text { specimen }\end{array}$ & $\begin{array}{c}\text { Cutting } \\
\text { speed, } \\
(\mathrm{mm} / \mathrm{min})\end{array}$ & $\begin{array}{c}\text { Arc } \\
\text { current, I } \\
(\mathrm{A})\end{array}$ & $\begin{array}{c}\text { Cutting } \\
\text { height, } \\
\mathrm{H}(\mathrm{mm})\end{array}$ \\
\hline 1 & 2000 & 45 & 1 \\
\hline 2 & 2000 & 65 & 1 \\
\hline 3 & 2000 & 85 & 1 \\
\hline 4 & 4000 & 45 & 1 \\
\hline 5 & 4000 & 65 & 1 \\
\hline 6 & 4000 & 85 & 1 \\
\hline 7 & 6000 & 45 & 1 \\
\hline 8 & 6000 & 65 & 1 \\
\hline 9 & 6000 & 85 & 1 \\
\hline
\end{tabular}

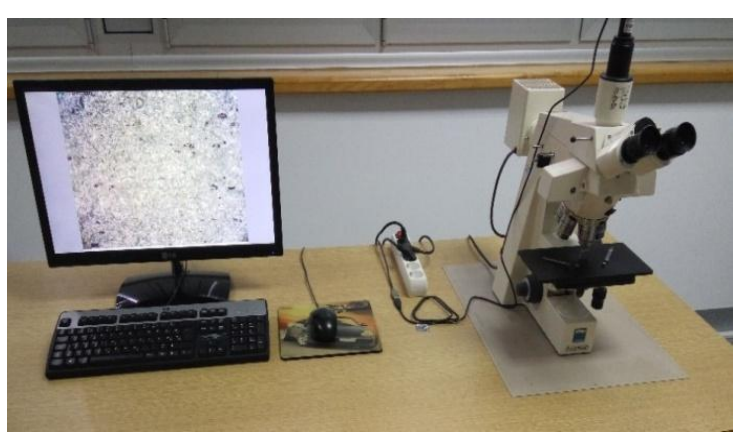

Figure 1. OPTON Axioskop optical microscope

Slika 1. OPTON Axioskop optički mikroskop

Testing samples were taken from the sheet parts that were cut by plasma jet process at certain values of the input factors. The process of gathering samples was conducted by cutting process, with the use of appropriate cooling agent. The samples were then grinded by the use of abrasive paper sheets with different granulation, and polished. For metallographic analysis, samples were etched with etching agent ordinarily used for microstructure development purposes of the aluminium alloys. It consisted of $0,5 \mathrm{~mL}$ of $40 \% \mathrm{HF}$ (Hydrofluoric Acid) dissolved in $100 \mathrm{~mL}$ of water, at room temperature.

The metallographic analysis was done on optical microscope OPTON Axioskop with connected DinoEye digital camera (Figure 1).

\section{RESULTS AND DISCUSSION}

The metallographic analysis results for chosen samples are presented on Figures 2 and 3.

Hardness testing was carried out on microhardness tester Shimadzu HMV-2T (Figure 4), with testing load of $9.8 \mathrm{~N}$ (HV1), in distances of $0.3 \mathrm{~mm}$ from the cutting edge towards center of the samples. For each of the gained hardness values, 3 measurements were done (Figure 5).
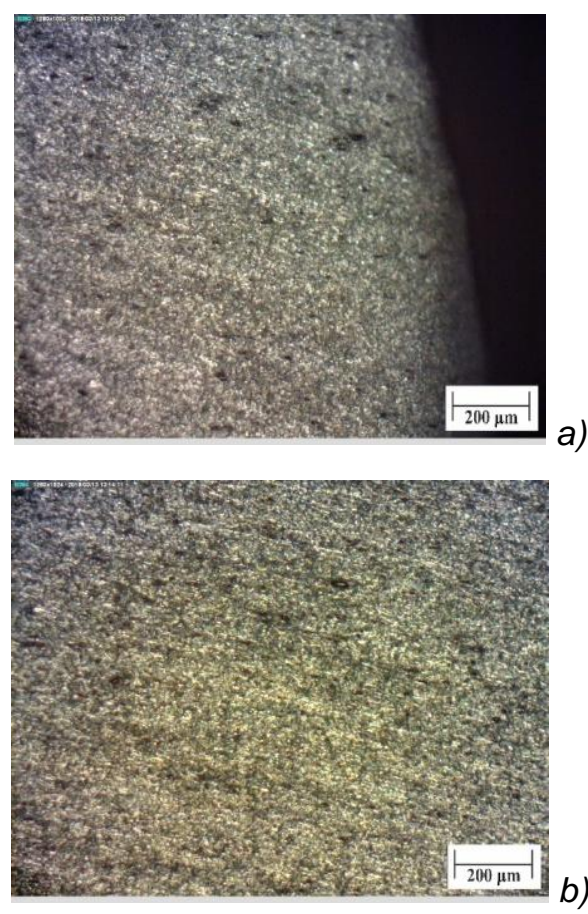

Figure 2. Metallographic image of: a) heat affected zone and b) base material for the sample No. 9

Slika 2. Metalografske slike: a) zone utjecaja topline i b) osnovnog materijala za uzorak br. 9
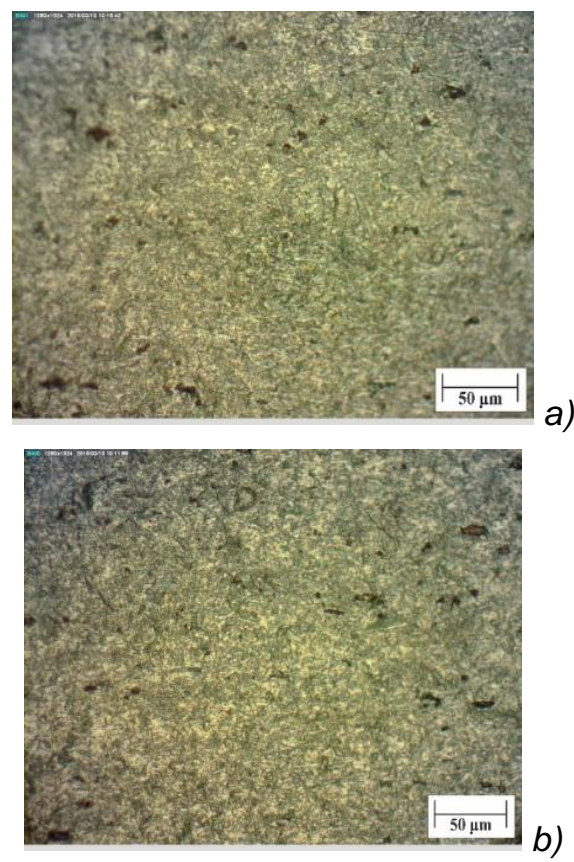

Figure 3. Metallographic image of: a) heat affected zone and b) base material for the sample No.6

Slika 3. Metalografske slika: a) zone utjecaja topline i b) osnovnog materijala za uzorak br. 6

The average values of measured hardness are given in Table 2. Based on obtained results, the histogram diagrams of micro-hardness values change dependency on distance of the cutting 
edge (Figure 6.1. - 6.9) and different cutting process input parameters (Figure 6.1. - 6.9, 7 and $8)$, are presented.

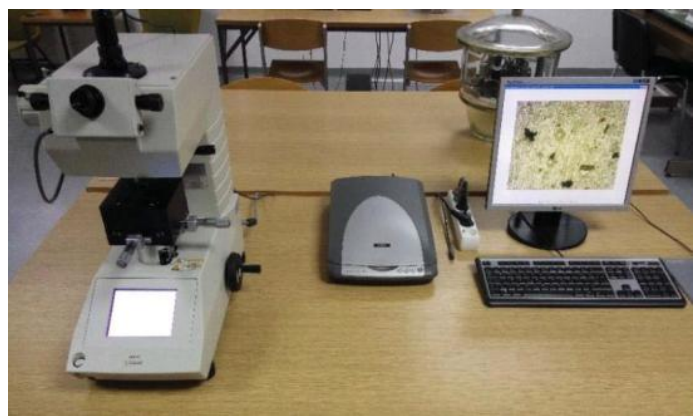

Figure 4. Micro hardness tester Shimadzu HMV-2T

Slika 4. Mikrotvrdomjer Shimadzu HMV-2T

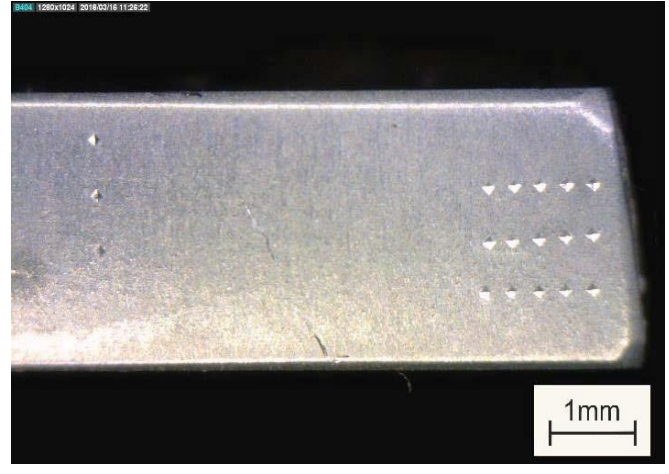

Figure 5. Micro-hardness testing positions

Slika 5. Pozicije mjerenja mikrotvrdoće

The difference between maximum measured hardness at $0.3 \mathrm{~mm}$ distance from the cutting edge and the hardness measured at the center of the sample is also shown on Figures 6.1. - 6.9.

Table 2. Micro hardness testing results on various distances from the cutting edge

Tablica 2. Rezultati mjerenja mikrotvrdoće na različitim udaljenostima od ruba reza

\begin{tabular}{|c|c|c|c|c|c|c|c|}
\hline \multirow{2}{*}{ Specimen No. } & \multicolumn{6}{|c|}{ Distance from the cutting edge, $(\mathrm{mm})$} \\
\cline { 2 - 7 } & 0.3 & 0.6 & 0.9 & 1.2 & 1.5 & Center of specimen cross section \\
\cline { 2 - 7 } & \multicolumn{9}{|c|}{ Hardness HV1 } \\
\hline 1 & 80.1 & 79.9 & 79.7 & 79.7 & 79.5 & 79.5 \\
\hline 2 & 83.0 & 81.0 & 80.9 & 80.6 & 80.2 & 80.2 \\
\hline 3 & 87.5 & 84.9 & 81.2 & 79.6 & 77.6 & 77.5 \\
\hline 4 & 79.5 & 78.4 & 78.0 & 77.5 & 77.3 & 77.3 \\
\hline 5 & 82.1 & 81.4 & 81.0 & 80.1 & 80.0 & 80.0 \\
\hline 6 & 87.8 & 83.3 & 80.7 & 80.6 & 78.1 & 78.0 \\
\hline 7 & 81.5 & 80.7 & 80.5 & 79.8 & 78.9 & 78.4 \\
\hline 8 & 81.9 & 80.3 & 79.1 & 78.0 & 77.7 & 77.7 \\
\hline 9 & 83.8 & 81.7 & 80.4 & 79.8 & 79.5 & 79.4 \\
\hline
\end{tabular}

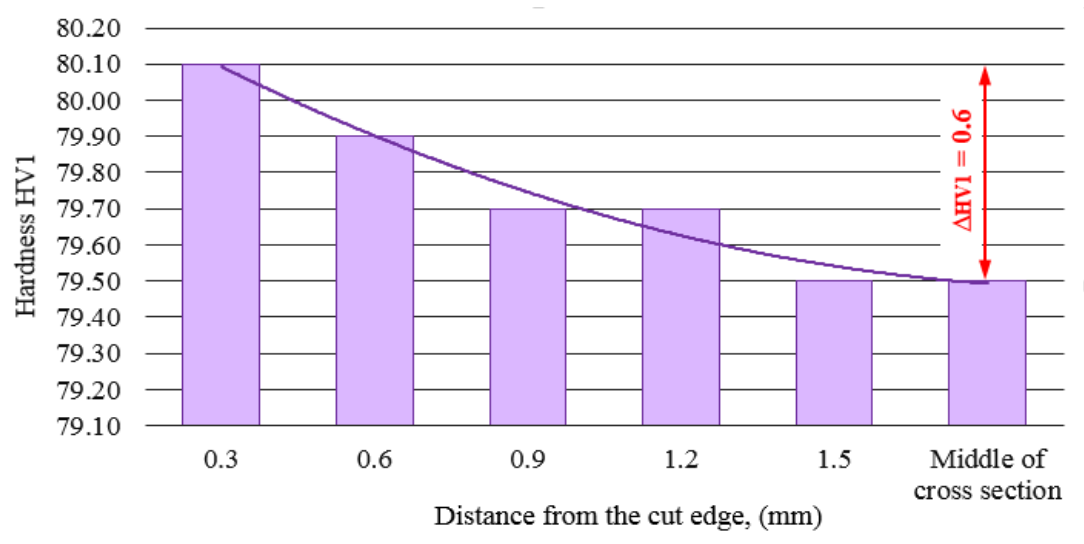

Figure 6.1. Diagram of micro-hardness value change dependency on the increase of distance from cutting edge - sample No. 1

Slika 6.1. Dijagram promjene mikrotvrdoće u ovisnosti o povećanju udaljenosti od ruba reza - uzorak br. 1 


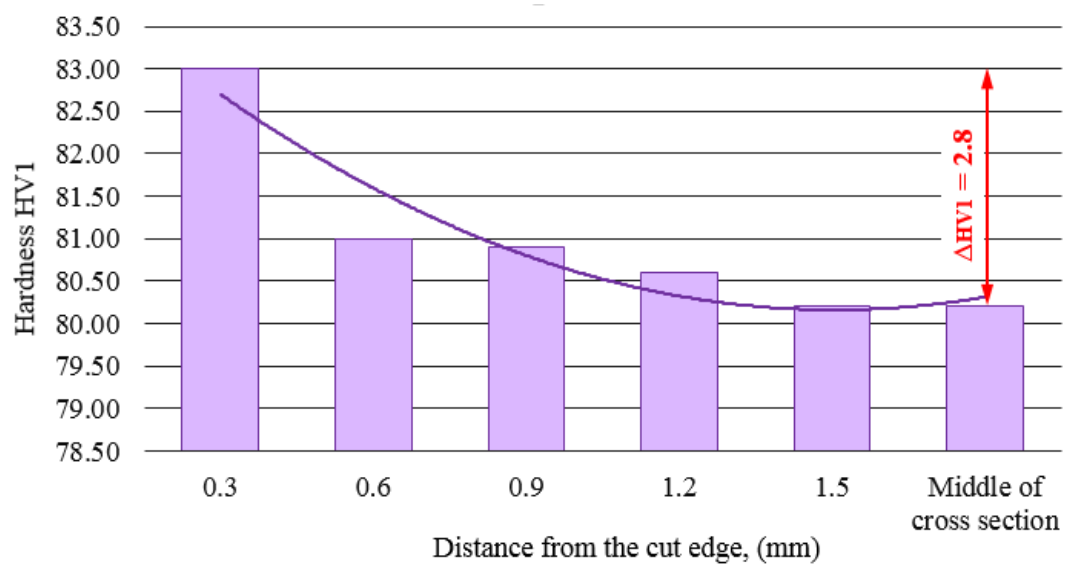

Figure 6.2. Diagram of micro-hardness value change dependency on the increase of distance from cutting edge - sample No. 2

Slika 6.2. Dijagram promjene mikrotvrdoće u ovisnosti o povećanju udaljenosti od ruba reza - uzorak br. 2

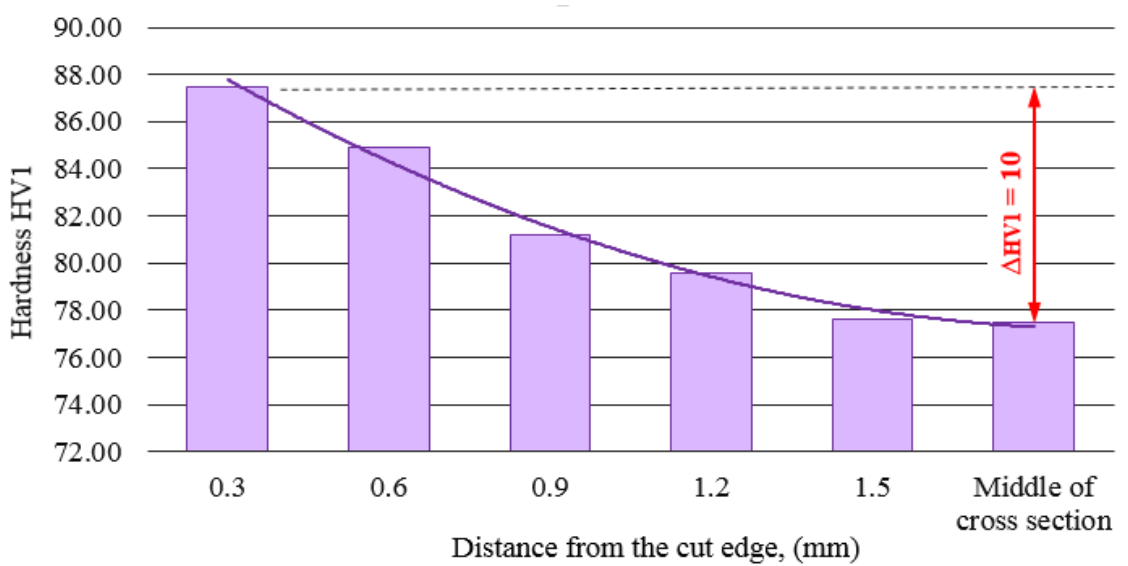

Figure 6.3. Diagram of micro-hardness value change dependency on the increase of distance from cutting edge - sample No. 3

Slika 6.3. Dijagram promjene mikrotvrdoće u ovisnosti o povećanju udaljenosti od ruba reza - uzorak br. 3

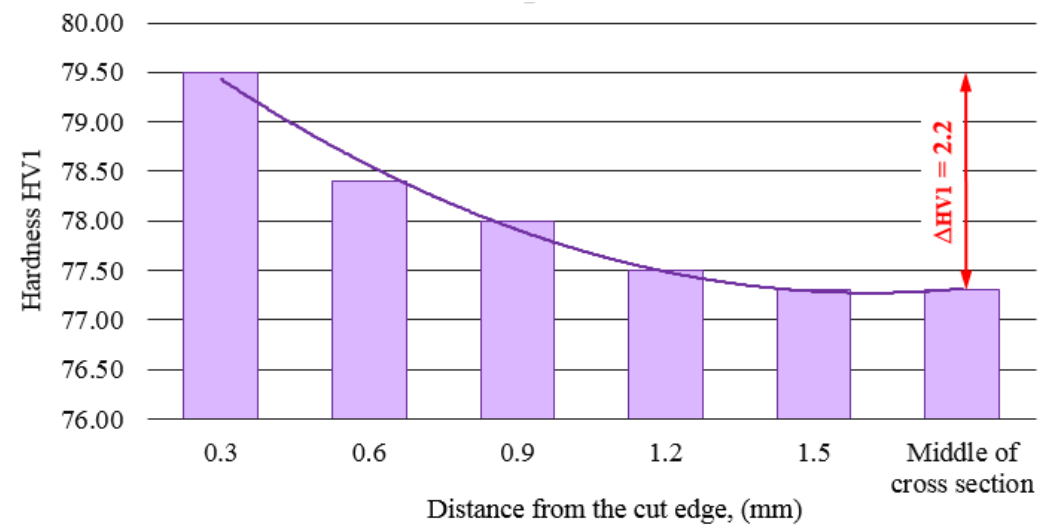

Figure 6.4. Diagram of micro-hardness value change dependency on the increase of distance from cutting edge - sample No. 4

Slika 6.4. Dijagram promjene mikrotvrdoće u ovisnosti o povećanju udaljenosti od ruba reza - uzorak br. 4 


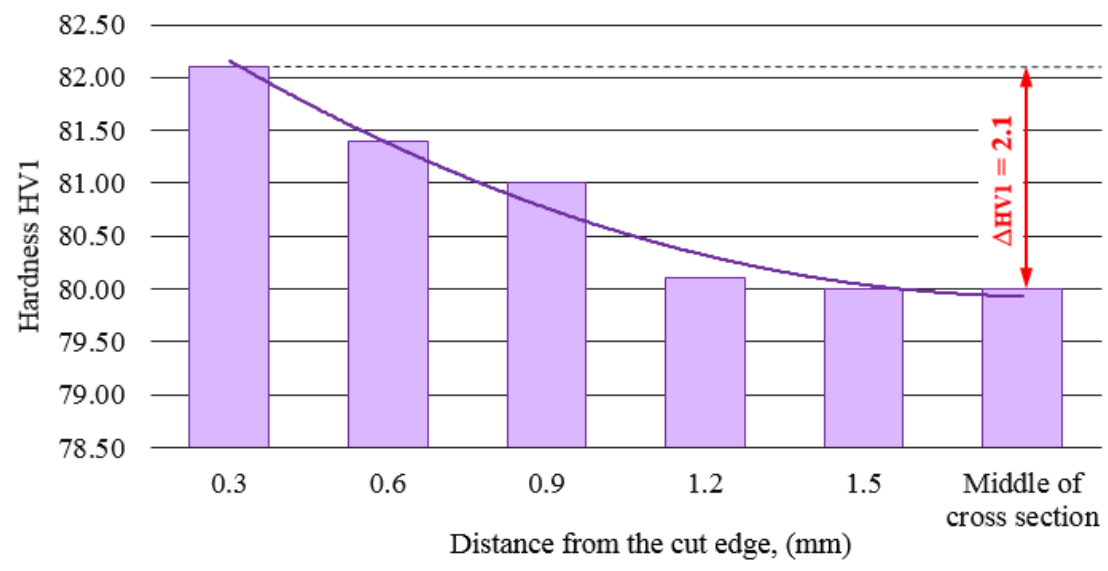

Figure 6.5. Diagram of micro-hardness value change dependency on the increase of distance from cutting edge - sample No. 5

Slika 6.5. Dijagram promjene mikrotvrdoće u ovisnosti o povećanju udaljenosti od ruba reza - uzorak br. 5

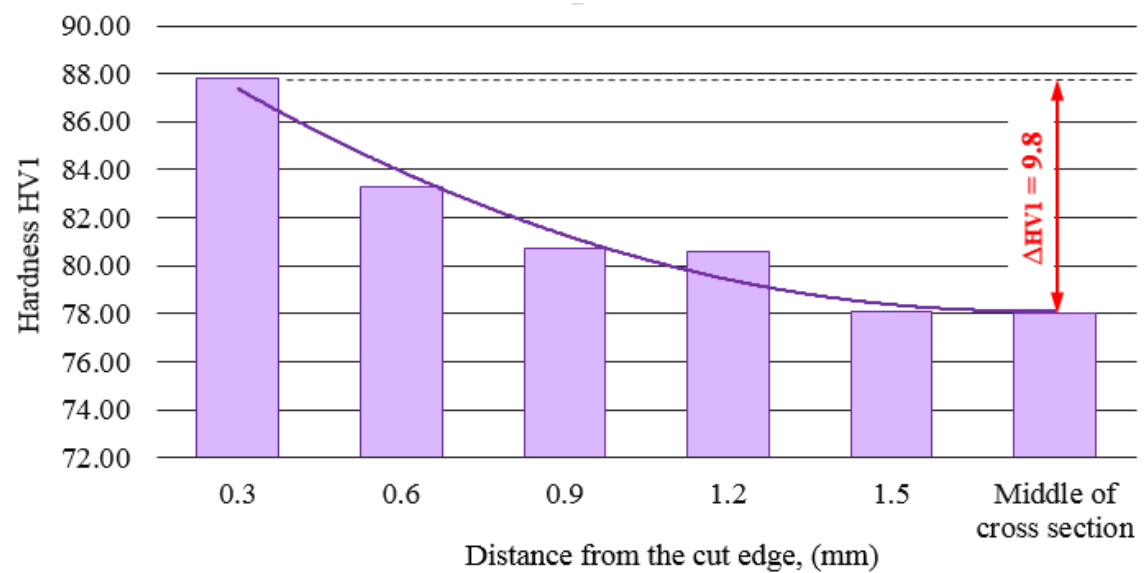

Figure 6.6. Diagram of micro-hardness value change dependency on the increase of distance from cutting edge - sample No. 6

Slika 6.6. Dijagram promjene mikrotvrdoće u ovisnosti o povećanju udaljenosti od ruba reza - uzorak br. 6

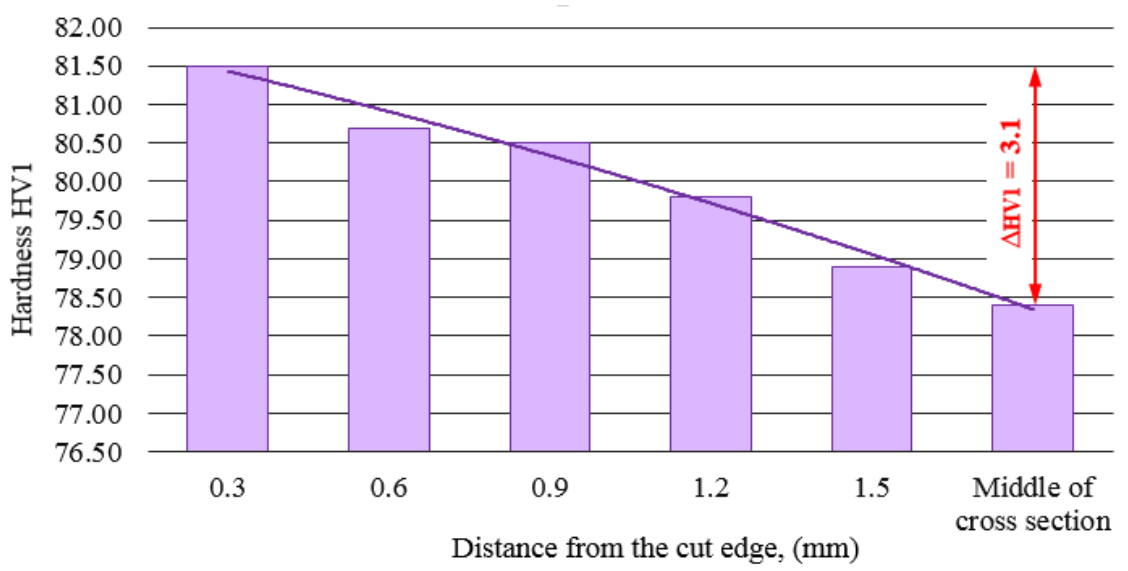

Figure 6.7. Diagram of micro-hardness value change dependency on the increase of distance from cutting edge - sample No. 7

Slika 6.7. Dijagram promjene mikrotvrdoće u ovisnosti o povećanju udaljenosti od ruba reza - uzorak br. 7 


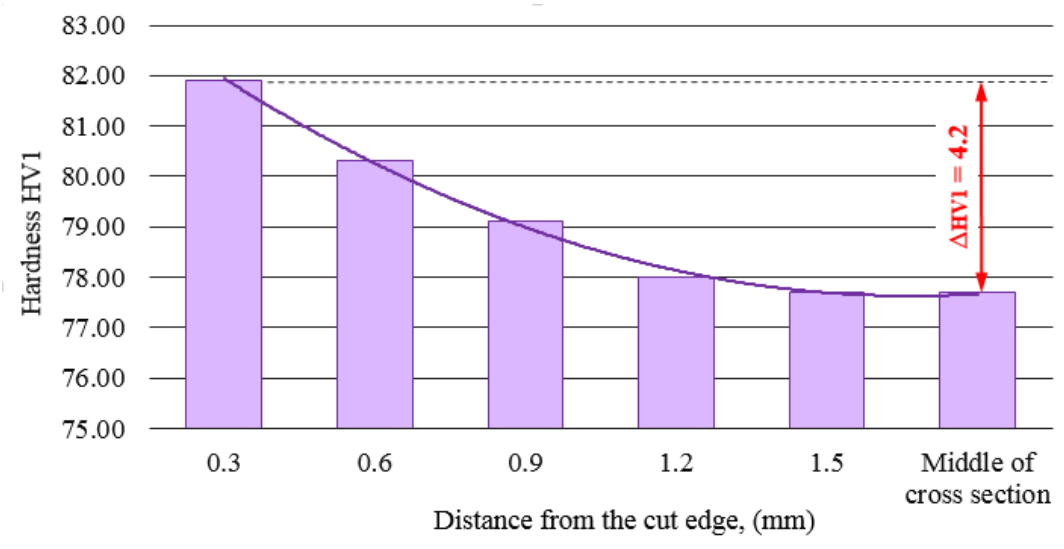

Figure 6.8. Diagram of micro-hardness value change dependency on the increase of distance from cutting edge - sample No. 8

Slika 6.8. Dijagram promjene mikrotvrdoće u ovisnosti o povećanju udaljenosti od ruba reza - uzorak br. 8

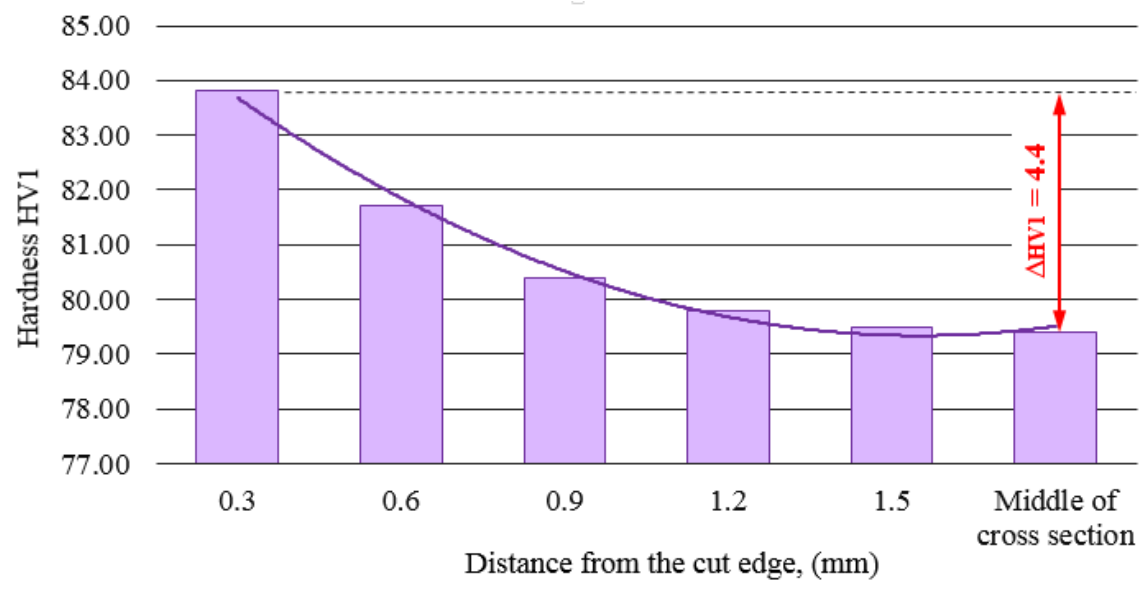

Figure 6.9. Diagram of micro-hardness value change dependency on the increase of distance from cutting edge - sample No. 9

Slika 6.9. Dijagram promjene mikrotvrdoće u ovisnosti o povećanju udaljenosti od ruba reza - uzorak br. 9

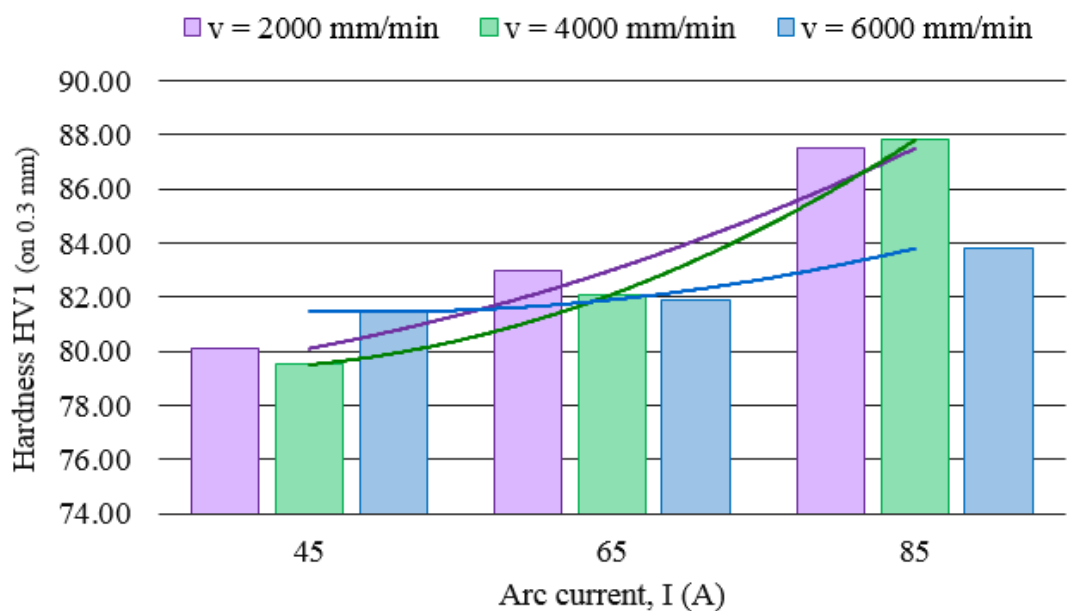

Figure 7. Diagram of micro-hardness value change dependency on electric current change for different values of cutting speed

Slika 7. Dijagram promjene mikrotvrdoće u ovisnosti o promjeni jakosti struje za različite vrijednosti brzine rezanja 


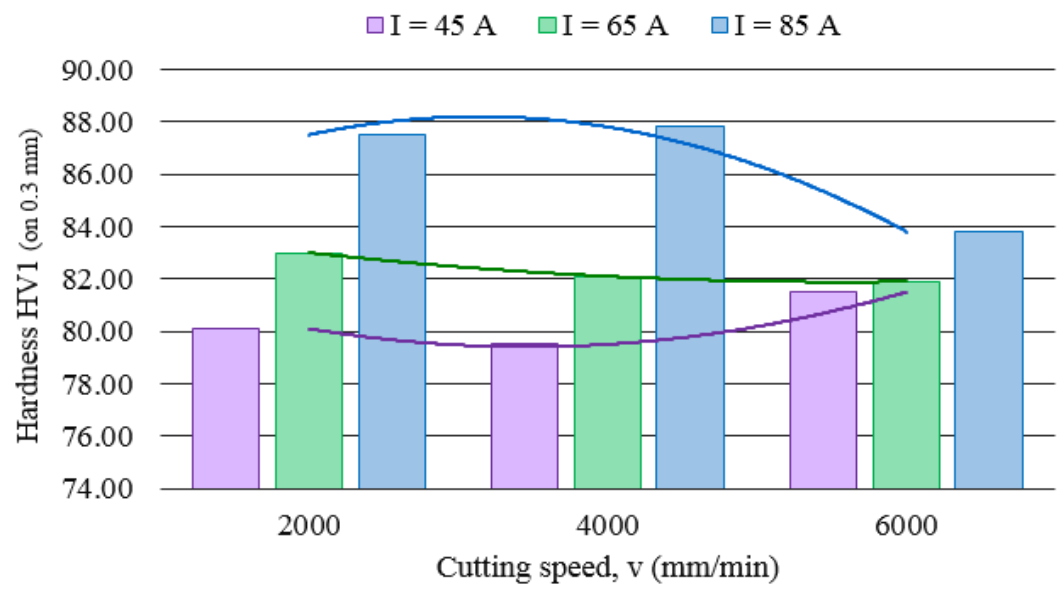

Figure 8. Diagram of micro-hardness value change dependency on cutting speed change for different values of electric current

Slika 8. Dijagram promjene mikrotvrdoće u ovisnosti o promjeni brzine rezanja za različite vrijednosti jakosti struje

On all of the metallographic images obtained, beside usually expected phases in the material structure, the existence of dark areas (inclusions), was noticed. For the purpose of properties analysis of the mentioned structural features, microhardness testing was conducted with $98.07 \mathrm{mN}$ load applied (HV 0.01), figure 9. In this figure, the indentation mark of micro-hardness measurement for usual phases was noted with a circle, with obtained values of $78 \mathrm{HV} 0.01$. On the same figure, the indentation marks of micro-hardness measurements for dark areas were noted with squares. Obtained values were $95 \mathrm{HV} 0.01$. The results have showed that dark areas do not represent any form of porosity in the material structure. It is possible that these areas imply certain precipitates. For more precise definition, SEM analysis ought to be conducted.

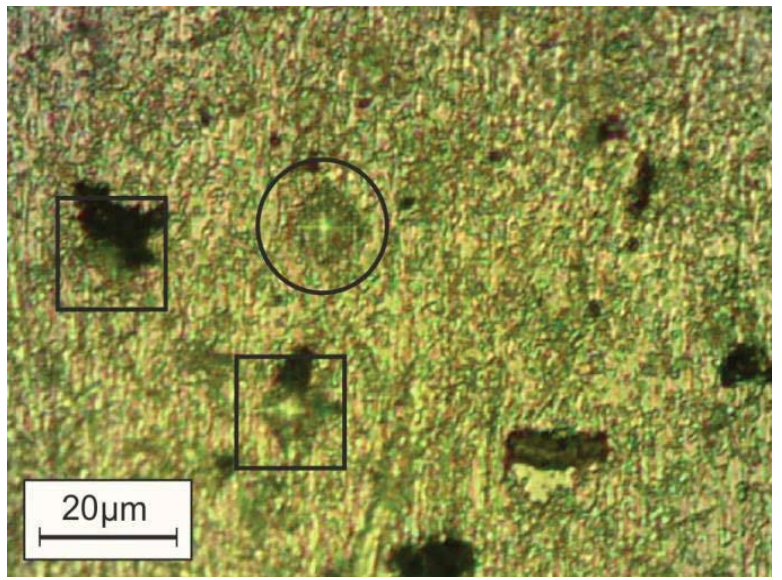

Figure 9. Micro-hardness testing of different phases in material structure

Slika 9. Mjerenje mikrotvrdoće različitih faza u strukturi materijala

\section{CONCLUSION}

Based on the obtained results of the microhardness analysis, as well as microstructure analysis, it can be concluded that significant structural changes in the heat affected zone did not occur. In fact, here is the case of non heattreatable aluminum alloy, which is not sensitive to the heat input during plasma jet cutting process, therefore significant hardness changes did not occur. Significant structural changes are expected to occur during cutting process, particularly during welding process, of the heat-treatable alloys. In the heat affected zone of these alloys, heat treatment effects would be undone, for the reason of the intermetallic compound precipitates grain size going larger, which would eventually lead to hardness and material strength values decrease.

\section{REFERENCES}

[1] I.Peko, B.Nedić, A.Đorđević, I.Veža (2018) Modeling of kerf width in plasma jet metal cutting process using ANN approach, Technical Gazette, 25(2), 401-406.

[2] I.Peko, B.Nedić, A.Đorđević, S.Đurić, D.Džunić, I.Veža, M.Janković (2017) Prediction of surface roughness in plasma jet cutting process using neural network model, Proceedings of $15^{\text {th }}$ International Conference on Tribology, p.525.

M.Kumar Das, K.Kumar, T.K.Barman, P.Sahu (2014) Optimization of process parameters in plasma arc cutting of EN31 steel based on MRR and multiple roughness characteristics using grey relational analysis, Procedia Materials Science, 5, 1550-1559.

[3] R.Bini, B.M.Colosimo, A.E.Kutlu, M.Mono (2008) Experimental study of the features of the kerf generated by a 200 A high tolerance plasma arc cutting system, Journal of Materials Processing Technology, 196, 345-355. 
[4] A.Gullu, U.Attici (2006) Investigation of the effects of plasma arc parameters on the structure variation of AISI 304 and St 52 steels, Materials and Design, 27, 1157-1162.

[5] E.Gariboldi, B.Previtali (2005) High tolerance plasma arc cutting of commercially pure titanium, Journal of Materials Processing Technology, 160, 77-89.

[6] S.Chamarthi, N.Reddy Sinivasa, M.Elipey Kumar, D.V.Reddy Ratmana (2013) Investigation analysis of plasma arc cutting parameters on the unevenness surface of Hardox 400 material, Procedia Engineering, 64, 854-861.
[7] B.Nedić, M. Janković, M.Radovanović, G.Globočki Lakić (2013) Quality of plasma cutting, Proceedings of the International Conference on Tribology, 314319.

[8] M.Radovanović, M.Madić (2011) Modeling the plasma arc cutting process using ANN, Nonconventional Technologies Review, 4, 43-48.

[9] I.Peko, B.Nedić, A.Đorđević, D.Džunić, M.Janković, I.Veža (2016) Modeling of surface roughness in plasma jet cutting process of thick structural steel, Tribology in Industry, 38(4), 522-529.

\section{IZVOD}

\section{ANALIZA ZONE UTICAJA TOPLINE KOD PLAZMA REZANJA NA LEGURI ALUMINIJA EN AW 5083}

Rezanje plazmom je poznati nekonvencionalni termo-električni proizvodni postupak koji se ponajviše koristi u metalnoj i brodograđevnoj industriji. Postupak koristi energiju visoko ioniziranog plina za rezanje različitih tipova metalnih materijala. Postupak rezanja je definiran tehnološkim parametrima čije vrednosti određuju kvalitetu završnog reza. Kvaliteta reza može se definirati različitim karakteristikama, kao što su: širina reza, kut nagiba, površinska hrapavost, visina srha $i$ zona uticaja topline. U ovom radu provedeno je istraživanje delovanja različitih parametara procesa na zonu uticaja topline (ZUT). Ispitivani materijal je bila legura aluminija EN AW 5083. Analiza zone uticaja topline izvršena je merenjem promene tvrdoće po poprečnom preseku uzoraka i mikroskopskom analizom strukture materijala.

Ključne reči: plazma rezanje, zona uticaja topline, aluminij, EN AW 5083, tvrdoća, struktura materijala.

Naučni rad

Rad primljen: 02. 01. 2019.

Rad prihvaćen: 15. 02. 2019.

Rad je dostupan na sajtu: www.idk.org.rs/casopis

(C) 2019 Authors. Published by Engineering Society for Corrosion. This article is an open access article distributed under the terms and conditions of the Creative Commons Attribution 4.0 International license (https://creativecommons.org/licenses/by/4.0/) 